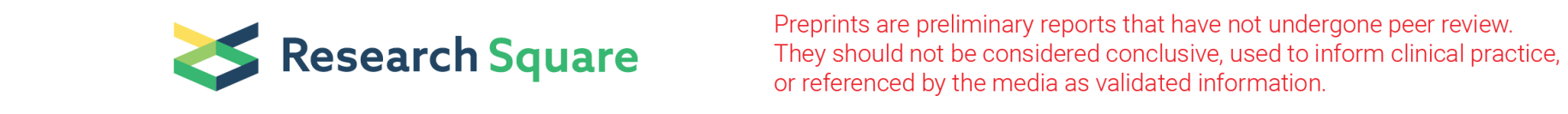

\title{
Unravelling the Differential Expression of Potential microRNAs in Bacterial Wilt-resistant and Susceptible Ginger Species
}

\author{
M Snigdha \\ ICAR-Indian Institute of Spices Research \\ D Prasath ( $\sim$ Prasath.D@icar.gov.in ) \\ ICAR-Indian Institute of Spices Research
}

\section{Research Article}

Keywords: MicroRNAs (miRNA), Ralstonia solanacearum, ginger-Ralstonia solanacearum, Curcuma amada

Posted Date: December 4th, 2020

DOl: https://doi.org/10.21203/rs.3.rs-115945/v1

License: @ (i) This work is licensed under a Creative Commons Attribution 4.0 International License. Read Full License 


\section{Abstract}

MicroRNAs (miRNA) have been shown to regulate plant pathogen interaction, by silencing genes, destructing or blocking of the translation of mRNA. However, their role in bacterial wilt, caused by Ralstonia solanacearum in ginger, has not been studied. In the present study, we utilized the transcriptome data from ginger-Ralstonia solanacearum interactions to characterize miRNAs from bacterial wilt-susceptible ginger (Zingiber officinale) and resistant mango ginger (Curcuma amada). The assembled mRNAs were utilized to generate miRNA targets and miRNAs. Considering the alignment results, we located a total of 2926 potential miRNA targets out of which 1551 were upregulated and 1419 were downregulated in ginger. In case of mango ginger, out of 2145 potential miRNA targets, 1506 were upregulated and 1594 were downregulated. In the resistance interactions with mango ginger, 1068 unique target genes were upregulated when compared to control. Gene Ontology (GO) analysis of differentially expressed target genes showed highest enrichment in response to cold, chloroplast and ATP binding in biological, cellular and molecular functions respectively. Nine target genes and their corresponding miRNAs were experimentally validated, which shows significant difference in expression with ginger-Ralstonia solanacearum interactions. The results will be very useful to disease resistant varieties of ginger.

\section{Introduction}

India is rich in spices and has been considered as the "Spice Bowl of the World" and a major reason for foreigners to invade India. Ginger (Zingiber officinale Rosc.) the main spice, a medicinal crop is cultivated mostly in tropical and subtropical areas of the India ${ }^{1}$. The rhizomes which contain several bioactive compounds used as a flavoring agent, herbal medicine and is also employed in the perfume industry ${ }^{1,2}$. India is the largest ginger producer, accounting for more than $32 \%$ of world total ${ }^{3}$. But unfortunately, disturbing reports regarding the crop loss due to bacterial wilt caused by Ralstonia solanacearum has been coming out ${ }^{2}$. Bacterial wilt is considered as a severe disease especially in regions with warm climates ${ }^{4}$. India has crossed yield losses more than $50 \%$ due to this infection ${ }^{5}$. $R$. solanacearum, a soil-borne bacterium causes bacterial wilt in more than 50 plant families such as tomato, potato, pepper, peanut, banana, eggplant, ginger, etc. around the world ${ }^{6}$. This gram-negative bacterium infects plants through axils of secondary roots, which later invades cortex and then translocates and colonizes in the xylem vessels causes wilt symptoms and death ${ }^{7}$.

Many recent studies have increasingly concentrated on host plant resistance than compared with traditional chemical treatments, which seems to be way more powerful and economical way of controlling bacterial wilt infection (Kumar et al. 2004, Ghosh and Mandal 2009, Kumar and Sarma 2012). Several enhanced resistance variety of potatoes, tomatoes, peanut, eggplant, and banana have been successfully generated by transformation of the resistant gene to the plant (Chen et al. 2006, Hong et al. 2013). A few researches has been carried out to identify resistance source to Ralstonia induced bacterial wilt in ginger; few were successful. In a study in our lab ${ }^{10}$ the ICAR-Indian Institute of Spices Research, Kozhikode, Kerala identified mango ginger (Curcuma amada), which is from ginger family Zingiberaceae, showing a high level of resistance against Ralstonia wilt infection. A comparative transcriptomics adopted by our laboratory to compare trancriptomes of ginger and mango ginger during bacterial wilt has enabled in identifying a considerable number of defense response genes, which can be utilized studying pathways involved in resistance to the bacterial wilt.

Enumerable corroboration states that microRNAs (miRNAs) are hypersensitive to diverse physiologic processes such as abiotic or biotic stress ${ }^{11,12}$. miRNAs which are approximately 21-nucleotide noncoding RNAs serves a crucial role in posttranscriptional gene regulation by degrading target mRNAs in plants. Preceding research exposes several plant miRNAs and their target which are biotic stress related. This advocate that miRNAs are crucial to the stress response of plants ${ }^{13,14}$. Thus far, the miRNA expression profiles of ginger under bacterial stress conditions have rarely been reported. Efforts to identify bacterial wilt responsive miRNAs and determine their expression patterns would improve our understanding of their functions in stress adaptation.

Several researchers reported that pathogen attack in plants induce numerous miRNAs and later control and contribute towards the reprogramming of gene expression. It was reported that during wheat-stripe rust infection several variants of known

Page 2/21 
miRNAs, and 163 candidate novel wheat miRNAs were differential expressed ${ }^{12}$. Lot of research has been carried out to overexpress significant miRNAs to enhance disease resistance in the susceptible plants. Overexpressing miR319b in rice found to be a positive regulator of the rice defense response against the blast disease ${ }^{15}$. Differential expression of miRNAs were observed in wheat and barley after infection with powdery mildew ${ }^{16,17}$. Introduction of artificial miRNA has been carried out in several plants against viral infection such as wheat, maize, tomato grape wine ${ }^{18-20}$.

In this study, we employed high-throughput sequencing technology to characterize the changes ginger and mango ginger transcriptome following $R$. solanacearum infection. Integrated analysis of gene and miRNA datasets revealed miRNAs that involved in plant pathogen interaction, disease resistance and defense related pathways. Our results provided valuable information to reveal the molecular mechanisms between the interaction of bacterial wilt and ginger.

\section{Results}

\section{High throughput sequencing and identification of miRNA targets and miRNAs}

In order to study the role of miRNAs in response to bacterial wilt infection in ginger and mango ginger, already available transcriptome data from our laboratory was utilized. The first step was to predict the conserved target genes and later identify the miRNAs for each target using psRNATarget program.

Initially two RNA libraries were constructed and sequenced using Illumina ${ }^{10}$. These include control and treated ( $R$. solanacearum) rhizome of ginger and mango ginger respectively. In order to identify the potential target, RNA seq was utilized to reconstruct transcriptome de novo. A total of 80496326 and 66561960 raw reads, accounting approximately for mango ginger and ginger, respectively were generated using de novo. High quality reads were retained after removing the adapter, low quality sequences and PCR duplicates from the raw data. These reads were used to assemble contigs and further used to identify miRNA targets.

The results of de novo transcriptome assembly are summarized in Table 2 . The mango ginger assembly was represented by 307952 contigs with average of 845.32 bps, while ginger assembly was represented by 303878 contigs with average contig size of 692.32 bps. The N50 for mango ginger and ginger with de novo assemblies were 1256 and 1005, respectively.

\section{Expression of miRNA target in ginger and mango ginger in response to $R$. solanacearum infection}

Differentially expressed miRNA targets were identified at a significant level (adjusted p-value $<0.05$ and fold change $>-1.5$ ) by comparing normalized target expression level using CLC bio Genomic Workbench ver 6.0. After carefully considering the alignment results, we located a total of 2926 conserved miRNA targets out of which 1551 were upregulated and 1594 were downregulated in ginger. In case of mango ginger, out of 2145 conserved miRNA targets, 1506 were upregulated and 1419 were downregulated (Fig. 1 and 2).

\section{Identification of miRNAs from miRNA targets}

The psRNA Target server was utilized to upload target transcript and search their miRNAs. Each target gene was having several reverse complimentary sequences matching diverse miRNAs. These miRNAs were identified and screened. In case of ginger out of target genes maximum miRNAs were screened for gene UBC24_ARATH (1193). Out of all target genes 271 genes were having no sequence for miRNAs. In case of mango ginger, gene NFYA7_ARATH was having maximum number of complimentary sequences for miRNAs (320). No complimentary sequence for miRNAs were found for 315 target genes (Supplementary data 1) (Fig. 3).

Out of the common targets differentially expressed in both plants, nine were selected based their function and fold change. Primers were designed each target genes and their miRNAs (Table 1).

\section{GO and KEGG pathways differentially expressed target genes}


The predicted target genes in mango ginger and ginger had wide range of biological functions in response reaction against cold, abscisic acid, protein autophosphorylation, regulation of transcription etc. Chloroplast, plasma membrane, nucleus, cytoplasm were enriched maximum in cellular components. The main molecular function enriched were ATP binding, metal ion binding, protein serine activity etc (Fig. 4). KEG analysis was carried out for target genes to understand the gene regulation and its functions (Fig. 5).

\section{Different response of ginger and mango ginger to bacterial wilt}

As previously reported ginger and mango ginger was showing different response during our experiment. Ginger was showing downward drooping within $48 \mathrm{~h}$ post inoculation. By fifth day leaves become yellow and vascular browning started. Affected rhizome become dark brown in color and was exudating milky white fluid upon cut. No one of these symptoms were shown by mango ginger (Fig. 6).

\section{Validation and differential expression of analysis of miRNA target genes}

The qPCR further validated nine selected miRNA target genes (4CLL1, ABCC5, PRT6, RSP2, FRS6, AAP4, WRKY19, ABCG11 and DNAJ1) and demonstrated their differential expression in leaf and rhizome of both ginger and mango ginger after infecting bacterial wilt. All target genes were having significant differential expression with mango ginger. Out of nine target genes in ginger 7 and 8 target genes upregulated in leaves and rhizome respectively. In case of mango ginger 6 target genes in leaves and 7 target genes in rhizome upregulated during bacterial wilt. Among these four target genes (4CLL1, ABCC5, PRT6 and RSP2) showed upregulation after bacterial wilt infection in leaves and rhizome of both ginger and mango ginger. In case of FRS6 and WRKY19 target genes of ginger were upregulated but was downregulated in mango ginger. AAP4 showed down regulation in ginger and upregulation in mango ginger. ABCG11 was upregulated in all samples except ginger leaves. In case of DNAJ1, an upregulation was seen in all samples except mango ginger leaves (Table 3).

The stem loop RT-PCR further validated miRNAs corresponding to each miRNA targets and demonstrated their differential expression in leaf and rhizome of both ginger and mango ginger after infecting bacterial wilt. After analyzing the expression of selected miRNA target genes and their miRNAs in ginger and mango ginger, correlation analysis was carried out using Pearson correlation coefficient. However, the expression profiles of all miRNAs were not perfectly negative corresponding to these targets. Data of miRNAs showing Pearson correlation coefficient with its corresponding miRNA target more than 0.9 is shown here (gra-miR482, mtr-miR5261, gma-miR4415, osa-miR169, ath-miR167, ppt-miR1223, aly-miR398, ath-miR1886 and mtrmiR164) (Fig. 7 and Table 4)

4CLL1 was upregulated in both rhizome and leaves in ginger and mango ginger. Expression of ginger with mango ginger was more prominent in rhizome when compared to leaves. The corresponding miRNA we studied were ath-miR1886.It was downregulated in both leaves of ginger and mango ginger but was upregulated in rhizome of mango ginger. There was a high negative correlation coefficient the target gene and its miRNA (Fig. 7).

ABCC5 is upregulated in both leaves and rhizome of both ginger and mango ginger. However, expression of mango ginger was significantly less when compared to ginger. Mtr-miR5261 was the miRNA we studied which has complimentary sequence with ABCC5. In both tissue of ginger and mango ginger this miRNA was downregulated. But there was a significant high expression in mango ginger when compared to ginger.

PRT6 was upregulated in the initial hours post inoculation in ginger leaves later it got down regulated. In case mango ginger it was upregulated in all time intervals. Even though PRT6 was upregulated in both ginger and mango ginger, there is a significant upregulation in rhizome of mango ginger when compared with ginger. When compared with PRT6, its miRNA (osa-miR169) expression way more less in both plants. It was downregulated in both leaves and tissue in ginger and mango ginger (Fig. 7).

Like PRT6, RSP2 was upregulated in the initial hours post inoculation in ginger leaves later it got down regulated. It was upregulated in rhizome of both ginger and mango ginger. There was a significant differential expression between them. Gra- 
miR482, its corresponding miRNA was downregulated in ginger and was upregulated in mango ginger in both leaves and rhizome (Fig. 7).

FRS6 was significantly differentially expressed in mango ginger when compared to ginger. It was upregulated in ginger but was downregulated in mango ginger in both leaves and rhizome. Ppt-miR1223 was showing high negative correlation among the corresponding miRNAs. There was a significant differential expression in only with rhizome of mango ginger when compared to ginger. A higher expression was shown in rhizome of mango ginger (Fig. 7).

AAP4 was mostly downregulated in both plants except for mango ginger rhizome. However, there was a significant differential expression between ginger and mango ginger. The miRNA corresponding for this target genes was mtr-miR164. Expression of this miRNA was higher in rhizome when compared to leaves. It was upregulated in both samples in almost all-time intervals (Fig. 7).

The expression of WRKY19 was upregulated in ginger leaves and downregulated in mango ginger leaves in all time intervals. However, rhizome showed a different pattern for mango ginger where it was mostly upregulated and ginger found to be downregulated in most of the time intervals. When miR98, the corresponding miRNA was checked for differential expression, leaves of both plants were downregulated, even though there was a significant differential expression. Although rhizome of mango ginger was upregulated and ginger downregulated (Fig. 7).

ABCG11 was showing significant differential expression in leaves of ginger when compared to mango ginger leaves. There was not much difference in expression in rhizome of both plants in all time intervals. Gma- miR4415 was the miRNA tested for differential expression here. There was downregulation in leaves and upregulation in rhizome for both ginger and mango ginger. Not much differential expression in leaves but was showing significant differential expression in rhizome (Fig. 7).

DNAJ1 was upregulated in ginger leaves and rhizome. In case of mango ginger it was downregulated in leaves and upregulated in rhizome. They were differentially expressed in all samples. In ath-miR167 the differential expression was there in all samples. However, ginger was downregulated in leaves and upregulated in rhizome and in case of mango ginger both tissue were upregulated.

There was a tremendous difference in fold change between mango ginger and ginger in rhizome and leaves. In case of target gene and its miRNA. In case of target gene, the range was between -15.8 to 28.08 in leaves (Supplementary Figure 1) and -7.1 to 18.1 in rhizome (Supplementary Figure 2). In case of miRNAs the fold change range was between -24.61 to 20.16 and -15.75 to 9.25 in mango ginger and ginger leaves respectively (Supplementary Figure 3). The fold change range was between -13.31 to 18.15 and -15.73 to 18.14 in mango ginger and ginger rhizome respectively (Supplementary Figure 4).

\section{Discussion}

Ginger has been cultivated in South Asia including India mostly as spice and also medicinal purpose ${ }^{21}$. Ginger is used as an anti-inflammatory and anti-oxidative ${ }^{22}$. Bacterial wilt is common disease in ginger which affects the vascular tissue. It blocks enters through root, blocks the xylem and eventually blocks of the water transport system. A bacterium named $R$. solanacearum has been identified as the main reason for bacterial wilt in ginger. Because of its mode of action it causes wilting in the ginger plants and kills the plant eventually ${ }^{2}$. Though there are several preharvest technologies to control bacterial wilt in ginger, its occurrence and persistence in ginger is not yet eliminated. In a previous study in our laboratory we reported mango ginger ( $C$. amada) which is resistant to bacterial wilt. Comparison of transcriptome data and later comparing real time PCR data of these susceptible and resistant variety gingers showed several candidate genes which were upregulated in mango ginger when compared to ginger. But the complete mechanism is still not fully studied.

There are several reports stating the importance of miRNA in eukaryotic gene expression. miRNAs targets the transcripts which contains highly complementary recognition sites. Later they then exert their repressive roles on gene expression ${ }^{23}$. Apart from few studies, the identification of miRNA and its role is not well studied in ginger. Moreover, a comparison of miRNA targets and 
its miRNA in mango ginger and ginger during bacterial wilt which give us much more clear idea about the reason of one being resistant to bacterial wilt.

Identification of target genes of miRNAs is crucial in understanding their functional implication. Our current study has led to the identification nine miRNA target genes which specifically got differentially expressed in ginger during bacterial wilt when compared to mango ginger. Moreover, were identified nine miRNAs which played important role in giving resistance to mango ginger.

4CLL (4-coumarate-CoA ligase) is considered as an important component in phenylpropanoid pathway. It mainly participates in biosynthesis of p-coumaroyl-CoA, a precursor for the production of p-coumaryl alcohol and coniferyl alcohol ${ }^{24}$. Coumarin accumulation is considered to be one of the most important response in infection with various virus, fungi and pathogen 25,26 . $R$. pseudosolanacearum infection in tobacco was controlled by hydroxycoumarin ${ }^{27}$. Importantly, p-coumaroyl-CoA is a precursor for the biosynthesis of several plant metabolites such as stilbenes and flavonoids ${ }^{28}$. In our study 4CLL1 was upregulated in both ginger and mango ginger during bacterial wilt, but when compared with ginger mango ginger was showing much higher expression in both rhizome and leaves. miR1886 was found to play important role in abiotic and biotic stress in various plants. miR1886 was found to be less expressed in response to ABA treatment which was related with an increase in Cf4CL transcripts ${ }^{29}$. In our work this ath-miR1886 showed differential expression in mango ginger rhizome expressed when compared to ginger leaves and rhizome (Fig. 7).

Though initially identified as transporters which plays in detoxification processes, later ABC transporters was shown to be required in stress responses, pathogen interaction ${ }^{30}$. In our study ABCC5, member of the superfamily of ATP-binding cassette $(A B C)$ transporters was shown to have differential expression during bacterial wilt. ABCC5 encodes a high-affinity inositol hexa kis phosphate transporter, which is known to play a part in guard cell signaling and phytate storage ${ }^{31}$. This protein was reported to play role in defense mechanism in several plants ${ }^{32-35}$. In present study, ABCC5 was upregulated in both ginger and mango ginger but significant differential expression was shown in rhizome of mango ginger. In our study, ABCC5 was having target sequence for mtr-miR5261 which was found to be more downregulated in mango ginger than ginger in both rhizome and leaves (Fig. 7).

PRT6 is a ubiquitin protein ligase which is a component of the N-end rule pathway. It regulates the biosynthesis of plantdefense metabolites such as glucosinolates, and the biosynthesis and response to the phytohormone jasmonate (JA), which plays a key role in plant immunity ${ }^{36}$. In our experiment PRT6 have shown to express more in mango ginger leaves and rhizome when compared to ginger during bacterial wilt. Among the various miRNAs corresponding to PRT6, osa-miR169 was shown to have maximum negative correlation. It is a conserved microRNA (miRNA) family which is reported to involved in plant growth development and responses induced by stress. In one report in rice osa-miR169 negatively regulate the immune response of rice against blast fungus Magnaporthe oryzae. It is proved that regulation is done by repressing the expression of nuclear factor solanacearum-a (NF-YA) genes. Moreover, osa-miR169 over expressed lines of transgenic rice was hyper susceptible to M. oryzae infection ${ }^{37}$. In our study it clearly shows that osa-miR169 was down regulated in both ginger and mango ginger in both cases but when compared with ginger, mango ginger was less expressed which in turn help the plant in disease resistance. Downregulation of this miRNA was shown in the early stages itself (Fig. 7).

NBS-LRR genes are one of the most studies disease resistance gene family in plants ${ }^{38}$. For example several studies have been carried out in these genes in giving resistance in wheat, cassava, sugarcane, rice, apple, coconut etc ${ }^{39-43}$. They are involved in the detection of various biotic stress such as pathogens, including bacteria, viruses, fungi, nematodes, insects and oomycetes. Their action can lead to plant cell death in the form of the familiar hypersensitive response (HR) ${ }^{39}$. We found a NBS-LRR protein RPS2 in our work which is also well studied in plants. It was reported to be found in plant cells were it protect plants against pathogens ${ }^{44-47}$. In one study it was showed that they can recognize AvrRpt2 type III effector avirulence protein from Pseudomonas syringae, which later triggers a defense response mechanism which inhibit pathogen invasion ${ }^{48}$. In our experiment there was a significant difference in expression of RSP2 in mango ginger when compare to ginger. The expression was higher in rhizome when compared to leaves. RSP2 was having target sequence for several miRNAs. Among them gra- 
miR482 showed highest negative correlation. It is an ancient and extensive family of miRNA present in all land plants. There is detailed publication on gra-miR482 cotton (Gossypium raimondii). It regulates the target site by cleaving and inhibiting the expression of target nucleotide binding sites and leucine-rich repeat (NBS-LRR) ${ }^{49}$. In ginger it is shown gra-miR482 is down regulated both the leaves and rhizome but has an upregulation in mango ginger both in leaves and rhizome even in the initial hours of infection itself (Fig. 7).

FRS6 (FAR1-related sequence 6) is a protein essential for phytochrome A controlled far-red responses in Arabidopsis. Loss-offunction mutants display elongated hypocotyls specifically under continuous FR light (FRc) (Lin and Wang, 2004). It was reported that during heat stress this gene was downregulated in, conic seagrass Posidonia oceanica Lazaro ${ }^{51}$. In our experiment FRS6 was upregulated in ginger whereas downregulated in mango ginger, proving its role in biotic stress caused by bacterial wilt. ppt-miR1223 was showing highest negative correlation with FRS6 when compared to other miRNAs. It targets mainly nucleic acid binding and secondary metabolic process. miR1223, was reported previously in Allium cepa ${ }^{52}$ and Physcomitrella patens ${ }^{53}$. Ppt-miR1223 was found to upregulate in rhizome of both ginger and mango ginger till $12 \mathrm{~h}$ post infection. Later this miRNA has shown to reduce expression in ginger rhizome (Fig. 7).

AAP4 is an amino acid permease which is an amino acid-proton symporter. It is a stereospecific transporter and has wide specificity for neutral amino acids, such as alanine, asparagine and glutamine ${ }^{54}$. Its reported that amino acid transporters play crucial role in plant defense by controlling the transport of amino acid ${ }^{54,55}$. AAP4 was found to be upregulated in mango ginger rhizome when compared to ginger leaves and rhizome. Mtr-miR164 which is its miRNA is conserved, highly expressed in fruits, and is validated to target a subset of genes of the NAC-domain transcription factor gene family ${ }^{56,57}$. It was found to have significant differential expression with mango ginger when compared with ginger in both leaves and rhizome (Fig. 7).

Wrky19 is a Transcription factor which act as a disease resistance protein with a serine/threonine-protein kinase activity ${ }^{58}$. The TIR-NB-LRR pair DSC1 and WRKY19 was reported in contributing basal immunity in Arabidopsis aganist the root-knot nematode Meloidogyne incognita ${ }^{59}$. Also overexpression of wheat WRKY gene TaWRKY19 increased the salt, drought, and freezing tolerance in transgenic plants ${ }^{60}$. In our experiments ginger surprisingly ginger leaves were showing high expression when compared to mango ginger. But in case of rhizome WRKY 19 was expressed more in mango ginger. The miRNA which was had highest correlation with WRKY19 was aly-miR398. It is a conserved miRNA that was identified in Arabidopsis by both computational prediction and sequence analysis of a stress-treated Arabidopsis small-RNA library ${ }^{61}$. In our experiment this miRNA was showing significant differential expression when compared with mango ginger (Fig. 7).

Another ABC transporter ABCC11 has reported to be involved in developmental plasticity and stress responses (Alvarado et al., 2004). In our study it was upregulated in rhizome and downregulated in leaves of both ginger and mango ginger. Both cases there was significant differential expression between ginger and mango ginger. In this study gma-miR4415 was shown to be regulating ABCG11. Gma-miR4415 was reported to have effect on soyabean during Asian soyabean rust infection ${ }^{64}$. Not much work has been carried out in in plants. Here this miRNA was shown to have upregulated in rhizome in the initial one hour and later in 24 hour in rhizome of mango ginger only. More work has to be carried out to clearly understand the exact role of this miRNA in ginger (Fig. 7).

DNAJ1 are heat shock proteins (HSPs) which are molecular chaperones known for their role in controlling inappropriate aggregation, folding, misfolding and unfolding of several proteins. They are reported to be involved in hyperosmotic and heat shock by preventing the aggregation of stress-denatured proteins and by disaggregating proteins. The Mirna sequence present in DNAJ1 we studied was ath-miR167. It is reported to be important in correcting the pattern of gene expression, and also for fertility in both ovules and anthers ${ }^{65}$. The differential expression of this miRNA in our plants shows an important role of this target gene and miRNA in plant resistance (Fig. 7).

All the nine miRNA targets and its corresponding miRNA studied were having significant differential expression when compared to mango ginger. This shows the importance of this genes giving resistance to mango ginger during bacterial wilt. 


\section{Conclusions}

We identified nine miRNA targets and miRNAs that showed significant differential expression in mango ginger during bacterial wilt by $R$. solanacearum. The potential targets of these miRNAs are involved in multiple biological processes, including defense response, cell differentiation, ATP binding and signal transduction. Our results are supporting the fact that miRNA-mediated networks control posttranscriptional regulation of bacterial wilt resistance in mango ginger. Our work provides useful information for further exploration of the mechanisms by which miRNAs function to improve ginger resistance.

\section{Methods}

\section{miRNA target and miRNA prediction囚}

The transcriptome data available from our lab ${ }^{10}$ was utilized to identify potent miRNA targets. The target genes of conserved miRNAs were predicted using psRNATarget program ${ }^{66}$. The following default parameters were used for identifying potential miRNA targets: (a) maximum expectation 5; (b) length for complementarity scoring (hspsize) 19 (c) range of central mismatch leading to translational inhibition 10-11 nucleotides. Same program was utilized to identify corresponding miRNAs for each miRNA.

Plant material

Ginger cv. IISR Varada and mango ginger cv. Amba were the varieties used for the experiment. Disease free rhizomes were obtained from the Experimental Farm of ICAR-Indian Institute of Spices Research, Peruvannamuzhi, Kerala, India. Sterile distilled water was used to wash the rhizome thoroughly. They were then planted in autoclaved perlite. The plants maintained under greenhouse conditions and were supplemented with half strength Hoagland solution.

\section{Inoculum preparation and inoculation procedure}

Virulent colonies of $R$. solanacearum strain GRs Mnt2 (108 CFU/ml) freshly grown in CPG agar were transferred into CPG broth and incubated at $28{ }^{\circ} \mathrm{C}$ for 16 solanacearum with constant shaking. Forty-five-day old plants were transferred to beakers containing $100 \mathrm{ml}$ virulent broth. Control plants were also kept in sterile water. Plants were maintained in green house conditions. Rhizome and leaves of both control and treated plants were collected during $0,1,4,8,12,24,48,72,96$ and 120 post inoculation (hpi) with $R$. solanacearum.

\section{miRNA isolation and cDNA synthesis}

Stem-loop qRT-PCR was used in expression profiling of selected miRNAs ${ }^{67}$. The miRNA fractions were isolated from leaves and rhizome using High Pure miRNA Isolation Kit (Sigma-Aldrich, USA) and the quantity were checked by Denovix spectrophotometer. In order to synthesize CDNA specific to each miRNA, one ug of miRNA was reverse transcribed with the stem-loop RT primers (5 pmol) specific for each miRNA using TaqMan microRNA reverse transcription kit [Applied Biosystems, Foster City, CA, USA]. The resulting cDNAs were diluted and used in Q- PCR reactions.

\section{Quantitative real-time PCR}

Real-time PCR analysis was performed using Quantifast SYBR Green Mastermix kit (Qiagen, USA) on the Rotor Gene Q RealTime PCR system (Qiagen, USA). MiRNA primers were designed using Primer-quest tool (Integrated DNA Technologies, Coralville, IA) (Table 1). Each $20 \mu \mathrm{L}$ reaction mixture contained $10 \mu \mathrm{L}$ of QuantiFast SYBR Green PCR Mastermix, $1 \mu \mathrm{L}$ of each primer $(10 \mathrm{mM}), 3 \mu \mathrm{L}$ of the template and $5 \mu \mathrm{L}$ of sterile distilled water. The thermal conditions were as follows: initial hold at $94^{\circ} \mathrm{C}$ for $5 \mathrm{~min}$ followed by 40 cycles at $94^{\circ} \mathrm{C}$ for $15 \mathrm{~s}$ and a final step at $60^{\circ} \mathrm{C}$ for $45 \mathrm{~s}$. Fold change of the transcripts was calculated relative to the control (0 hpi) using 2 -ddCt method using $\beta$-actin as an internal control ${ }^{68}$. The expression level of the miRNAs were normalized with expression of constitutive actin gene by subtracting the CT value of the miRNA of interest 
from the $\mathrm{CT}$ value of actin $(\triangle \mathrm{CT})$. The fold differences were transformed to a binary logarithm (log2). A melt curve analysis was run from 62 to $99^{\circ} \mathrm{C}$. The specificity each primer pair was analysed with single-peak melt curves.

\section{Construction of regulatory network using miRNA-mRNA}

Visualization of regulatory network between miRNA and mRNA was constructed using Cytoscape 3.7.1 ${ }^{69}$.

\section{Declarations}

\section{Acknowledgement}

This work was supported by the National post-doctoral fellowship (NPDF) research fund by Science and Engineering research Board (SERB), Government of India.

\section{References}

1. Ravindran, P., Sasikumar, B. \& George, J. Genetic resources of ginger (Zingiber officinale Rosc.) and its conservation in India. (IPGRI/FAO); Noticiario ... (1994).

2. Kumar, A. \& Sarma, Y. Characterization of Ralstonia solanacearum causing bacterial wilt in ginger. Indian Phytopathology (2012).

3. Viestad, A. Where Flavor Was Born. (2007).

4. Champoiseau, P. G., Associate, R., Jones, J. B. \& Allen, C. Ralstonia solanacearum Race 3 Biovar 2 Causes Tropical Losses and Temperate Anxieties. doi:10.1094/PHP-2009-0313-01-RV.

5. Ghosh, P. P. \& Mandal, N. C. Some disease management practices for bacterial wilt of potato. The Journal of Plant Protection Sciences1, 51-54 (2009).

6. Chen, S.-C., Liu, A.-R. \& Zou, Z.-R. Overexpression of glucanase gene and defensin gene in transgenic tomato enhances resistance to Ralstonia solanacearum. Russian Journal of Plant Physiology53, 671-677 (2006).

7. Turner, M. et al. Dissection of bacterial Wilt on Medicago truncatula revealed two type III secretion system effectors acting on root infection process and disease development. Plant physiology150, 1713-22 (2009).

8. Kumar, A., Sarma, Y. \& Anandaraj, M. Evaluation of genetic diversity of Ralstonia solanacearum causing bacterial wilt of ginger using REP-PCR and PCR-RFLP. Current Science (2004).

9. Hong, Y. et al. Expression of the MSI-99m Gene in Transgenic Potato Plants Confers Resistance to Phytophthora infestans and Ralstonia solanacearum. Plant Molecular Biology Reporter31, 418-424 (2013).

10. Prasath, D. et al. Comparison of the Transcriptomes of Ginger (Zingiber officinale Rosc.) and Mango Ginger (Curcuma amada Roxb.) in Response to the Bacterial Wilt Infection. PLoS ONE9, e99731 (2014).

11. Sunkar, R. \& Zhu, J.-K. Novel and stress-regulated microRNAs and other small RNAs from Arabidopsis. The Plant cel/16, 2001-19 (2004).

12. Ramachandran, S. R., Mueth, N. A., Zheng, P. \& Hulbert, S. H. Analysis of miRNAs in Two Wheat Cultivars Infected With Puccinia striiformis f. sp. tritici. Front. Plant Sci.10, (2020).

13. Phillips, J., Dalmay, T. \& Bartels, D. The role of small RNAs in abiotic stress. FEBS letters (2007).

14. Covarrubias, A. \& Reyes, J. Post-transcriptional gene regulation of salinity and drought responses by plant microRNAs. Plant, Cell \& Environment (2010).

15. Zhang, X. et al. Magnaporthe oryzae Induces the Expression of a MicroRNA to Suppress the Immune Response in Rice1[OPEN]. Plant Physio/177, 352-368 (2018).

16. Xin, M. et al. Diverse set of microRNAs are responsive to powdery mildew infection and heat stress in wheat (Triticum aestivum L.). BMC Plant Bio/10, 123 (2010). 
17. Hunt, M. et al. Small RNA discovery in the interaction between barley and the powdery mildew pathogen. $B M C$ Genomics20, 610 (2019).

18. Fahim, M., Millar, A. A., Wood, C. C. \& Larkin, P. J. Resistance to Wheat streak mosaic virus generated by expression of an artificial polycistronic microRNA in wheat. Plant Biotechnol. J.10, 150-163 (2012).

19. Kis, A. et al. Polycistronic artificial miRNA-mediated resistance to Wheat dwarf virus in barley is highly efficient at low temperature. Mol. Plant Pathol.17, 427-437 (2016).

20. Sun, L. et al. Dimeric artificial microRNAs mediate high resistance to RSV and RBSDV in transgenic rice plants. Plant Cell Tiss Organ Cult126, 127-139 (2016).

21. Park, E. J. \& Pezzuto, J. M. Botanicals in cancer chemoprevention. Cancer Metastasis Rev.21, 231-255 (2002).

22. Mashhadi, N. S. et al. Anti-Oxidative and Anti-Inflammatory Effects of Ginger in Health and Physical Activity: Review of Current Evidence. Int J Prev Med4, S36-S42 (2013).

23. Meng, Y., Shao, C., Wang, H. \& Chen, M. The Regulatory Activities of Plant MicroRNAs: A More Dynamic Perspective. Plant Physiology157, 1583-1595 (2011).

24. Li, Y., Kim, J. I., Pysh, L. \& Chapple, C. Four Isoforms of Arabidopsis 4-Coumarate:CoA Ligase Have Overlapping yet Distinct Roles in Phenylpropanoid Metabolism1[OPEN]. Plant Physio/169, 2409-2421 (2015).

25. Matern, U. Coumarins and other phenylpropanoid compounds in the defense response of plant cells. Planta Med.57, S1520 (1991).

26. Stringlis, I. A., de Jonge, R. \& Pieterse, C. M. J. The Age of Coumarins in Plant-Microbe Interactions. Plant Cell Physio/60, 1405-1419 (2019).

27. Yang, L. et al. Hydroxycoumarins: New, effective plant-derived compounds reduce Ralstonia pseudosolanacearum populations and control tobacco bacterial wilt. Microbiological Research215, 15-21 (2018).

28. Am, B. Evolution and current status of research in phenolic compounds. Phytochemistry vol. 68 https://pubmed.ncbi.nlm.nih.gov/17643453/ (2007).

29. Awasthi, P. et al. Characterization of the gene encoding 4-coumarate:CoA ligase in Coleus forskohlii. J. Plant Biochem. Biotechnol.28, 203-210 (2019).

30. Kang, J. et al. Plant ABC Transporters. Arabidopsis Book9, (2011).

31. Klein, M. et al. The plant multidrug resistance ABC transporter AtMRP5 is involved in guard cell hormonal signalling and water use. The Plant Journa/33, 119-129 (2003).

32. Martinoia, E., Klein, M., Schulz, B., Forestier, C. \& Müller-Röber, B. Production of plants with increased tolerance to drought stress or with increased transpiration. (2002).

33. Remy, E. et al. A major facilitator superfamily transporter plays a dual role in polar auxin transport and drought stress tolerance in Arabidopsis. The Plant Cel/25, 901-926 (2013).

34. Thakur, S., Choudhary, S. \& Bhardwaj, P. Comparative transcriptome profiling under cadmium stress reveals the uptake and tolerance mechanism in Brassica juncea. Journal of Plant Growth Regulation38, 1141-1152 (2019).

35. Wang, M., Liang, P. \& Jin, D. Expression of ABCC1-ABCC5 mRNA in the diamondback moth subject to chlorantraniliprole stress. Chinese Journal of Applied Entomology53, 581-588 (2016).

36. Marchi, R. de et al. The N-end rule pathway regulates pathogen responses in plants. Scientific Reports6, (2016).

37. Li, Y. et al. Osa-miR169 Negatively Regulates Rice Immunity against the Blast Fungus Magnaporthe oryzae. Front Plant Sci8, (2017).

38. Jones, D. A. \& Jones, J. D. G. The Role of Leucine-Rich Repeat Proteins in Plant Defences. in Advances in Botanical Research (eds. Andrews, J. H., Tommerup, I. C. \& Callow, J. A.) vol. 24 89-167 (Academic Press, 1997).

39. Belkhadir, Y., Subramaniam, R. \& Dangl, J. L. Plant disease resistance protein signaling: NBS-LRR proteins and their partners. Curr. Opin. Plant Biol.7, 391-399 (2004). 
40. Bozkurt, O., Hakki, E. E. \& Akkaya, M. S. Isolation and sequence analysis of wheat NBS-LRR type disease resistance gene analogs using degenerate PCR primers. Biochemical Genetics45, 469-486 (2007).

41. Lozano, R., Hamblin, M. T., Prochnik, S. \& Jannink, J.-L. Identification and distribution of the NBS-LRR gene family in the Cassava genome. BMC Genomics16, 360 (2015).

42. Rachana, K. E., Naganeeswaran, S. A., Fayas, T. P., Thomas, R. J. \& Rajesh, M. K. Cloning, characterization and expression analysis of NBS-LRR-type resistance gene analogues (RGAs) in coconut. Acta Botanica Croatica75, 1-10 (2016).

43. Wei, F. et al. The Mla (powdery mildew) resistance cluster is associated with three NBS-LRR gene families and suppressed recombination within a 240-kb DNA interval on chromosome 5S (1HS) of barley. Genetics153, 1929-1948 (1999).

44. Chelkowski, J., Tyrka, M. \& Sobkiewicz, A. Resistance genes in barley (Hordeum vulgare L.) and their identification with molecular markers. Journal of Applied Genetics44, 291-310 (2003).

45. Joshi, R. K., Kar, B., Mohanty, S., Subudhi, E. \& Nayak, S. Molecular cloning, characterization, and expression analysis of resistance gene candidates in Kaempferia galanga L. Molecular biotechnology50, 200-210 (2012).

46. Lalli, D. A. et al. Identification and mapping of resistance gene analogs (RGAs) in Prunus: a resistance map for Prunus. Theoretical and Applied Genetics111, 1504-1513 (2005).

47. Tao, Y., Yuan, F., Leister, R. T., Ausubel, F. M. \& Katagiri, F. Mutational analysis of the Arabidopsis nucleotide binding siteleucine-rich repeat resistance gene RPS2. Plant Cel/12, 2541-2554 (2000).

48. Mackey, D., Belkhadir, Y., Alonso, J. M., Ecker, J. R. \& Dangl, J. L. Arabidopsis RIN4 is a target of the type III virulence effector AvrRpt2 and modulates RPS2-mediated resistance. Cel/112, 379-389 (2003).

49. Zhu, Q.-H. et al. miR482 Regulation of NBS-LRR Defense Genes during Fungal Pathogen Infection in Cotton. PLoS One8, (2013).

50. Lin, R. \& Wang, H. Arabidopsis FHY3/FAR1 gene family and distinct roles of its members in light control of Arabidopsis development. Plant Physio/136, 4010-4022 (2004).

51. Marín-Guirao, L., Entrambasaguas, L., Ruiz, J. M. \& Procaccini, G. Heat-stress induced flowering can be a potential adaptive response to ocean warming for the iconic seagrass Posidonia oceanica. Molecular Ecology28, 2486-2501 (2019).

52. Mishra, R., Mohapatra, R., Mahanty, B. \& Joshi, R. K. Analysis of microRNAs and their targets from onion (Allium cepa) using genome survey sequences (GSS) and expressed sequence tags (ESTs). Bioinformation15, 907-917 (2019).

53. Talmor-Neiman, M. et al. Identification of trans-acting siRNAs in moss and an RNA-dependent RNA polymerase required for their biogenesis. The Plant Journal48, 511-521 (2006).

54. Wn, F., M, K., S, H. \& Wb, F. Substrate specificity and expression profile of amino acid transporters (AAPs) in Arabidopsis. The Journal of biological chemistry vol. 270 https://pubmed.ncbi.nlm.nih.gov/7608199/ (1995).

55. Yang, G., Wei, Q., Huang, H. \& Xia, J. Amino Acid Transporters in Plant Cells: A Brief Review. Plants9, 967 (2020).

56. Hernandez, Y., Goswami, K. \& Sanan-Mishra, N. Stress induced dynamic adjustment of conserved miR164:NAC module. Plant-Environment Interactions1, 134-151 (2020).

57. Rosas Cárdenas, F. D. F. et al. Effect of Constitutive miR164 Expression on Plant Morphology and Fruit Development in Arabidopsis and Tomato. Agronomy7, 48 (2017).

58. Eulgem, T., Rushton, P. J., Robatzek, S. \& Somssich, I. E. The WRKY superfamily of plant transcription factors. Trends Plant Sci5, 199-206 (2000).

59. Warmerdam, S. et al. The TIR-NB-LRR pair DSC1 and WRKY19 contributes to basal immunity of Arabidopsis to the rootknot nematode Meloidogyne incognita. BMC Plant Biology20, 73 (2020).

60. Niu, C.-F. et al. Wheat WRKY genes TaWRKY2 and TaWRKY19 regulate abiotic stress tolerance in transgenic Arabidopsis plants. Plant Cell Environ35, 1156-1170 (2012).

61. Jones-Rhoades, M. W. \& Bartel, D. P. Computational identification of plant microRNAs and their targets, including a stressinduced miRNA. Mol Cel/14, 787-799 (2004).

62. Alvarado, M. C. et al. Gene Trapping with Firefly Luciferase in Arabidopsis. Tagging of Stress-Responsive Genes. Plant Physiology134, 18-27 (2004).

Page $11 / 21$ 
63. Gene Trapping with Firefly Luciferase in Arabidopsis. Tagging of Stress-Responsive Genes | Plant Physiology. http://www.plantphysiol.org/content/134/1/18.

64. F, K., P, M., D, W. \& R, M. The role of MIR4415 in soybean response to asian soybean rust infection. BioTechnologia. Journal of Biotechnology Computational Biology and Bionanotechnology94, (2013).

65. Wu, M.-F., Tian, Q. \& Reed, J. W. Arabidopsis microRNA167 controls patterns of ARF6 and ARF8 expression, and regulates both female and male reproduction. Development133, 4211-4218 (2006).

66. X, D., Z, Z. \& Px, Z. psRNATarget: a plant small RNA target analysis server (2017 release). Nucleic acids research vol. 46 https://pubmed.ncbi.nlm.nih.gov/29718424/ (2018).

67. Varkonyi-Gasic, E., Wu, R., Wood, M., Walton, E. F. \& Hellens, R. P. Protocol: a highly sensitive RT-PCR method for detection and quantification of microRNAs. Plant Methods3, 12 (2007).

68. Santhi, R., Sheeja, T. E. \& Krishnamurthy, K. S. Transcriptome deep sequencing, identification of novel microRNAs and validation under drought stress in turmeric (Curcuma longa L.). Plant Biotechnol Rep10, 227-240 (2016).

69. Shannon, P. et al. Cytoscape: a software environment for integrated models of biomolecular interaction networks. Genome Res.13, 2498-2504 (2003).

\section{Tables}

Table 1. Primer designed for target genes to perform qPCR experiments 


\begin{tabular}{|c|c|}
\hline zo-PRT6 forward & CTTCGGCGTGCTTATTGGAA \\
\hline zo-PRT6 reverse & CCATCGAGGTAGCTGGACAT \\
\hline zo-FRS6 forward & CCAGAGCCCAAGTATCGGAA \\
\hline zo-FRS6 reverse & CAGGGTGGTTGTGGTCAATG \\
\hline zo-RPS2 forward & TTGCTCGCTTCACTGAGTTG \\
\hline zo-RPS2 reverse & GCCGCTTCAATCCTTCCAAT \\
\hline zo-WRKY19 forward & ACCAAGAGTGCAGAAGGTCA \\
\hline zo-WRKY19 reverse & ATGTGCCTTGCAGAAATGGG \\
\hline zo-ABCC5 forward & CCAGCTAAGAGACGCTGAGA \\
\hline zo-ABCC5 reverse & ACGCAGATACCAAAGGCAAC \\
\hline zo-4CCL1 forward & СTTCTCTCCTCGCGTCTGAT \\
\hline zo-4CLL1 reverse & AGCCGGAACTAGCTATCGTC \\
\hline zo-DNAJ1 reverse & ATGCCCTGAAGGAGGGAATG \\
\hline zo-DNAJ1 forward & АСТTССТССАССТССААAGG \\
\hline zo-AAP4 forward & TTGTCATCCACCTTGTCGGA \\
\hline zo-AAP4 reverse & GGGTGATGAACTCGCTCTTG \\
\hline zo-ABCG11 forward & GGAACGGTGTTGGATTCAGG \\
\hline zo-ABCG11 reverse & TCAGCAGCCTTAGCCAGTAG \\
\hline ca-PRT6 forward & ATGCATGCTTGGTGAGTCTG \\
\hline ca-PRT6 reverse & GCCTGCCCATTGTTCTTAGG \\
\hline ca-FRS6 forward & CCATCATGGCCAGTTGGTTT \\
\hline ca-FRS6 reverse & TCAGTAATGAGGGCCTTGGG \\
\hline ca-RPS2 forward & GGGAACCTAGCCCTCCAAAT \\
\hline ca-RPS2 reverse & CGTATCCAGCTTCACGCAAT \\
\hline ca-WRKY19 forward & AGGCCGGACTAGTTACTGTG \\
\hline ca-WRKY19 reverse & CACAATGTTTGCCАССТCCA \\
\hline ca-ABCC5 forward & GCTGCTCСTCTTCTTCCTGA \\
\hline ca-ABCC5 reverse & CAAACCGACCGAAACCTGAA \\
\hline ca-4CLL1 forward & CGTCAAGTTCAACGGACCTC \\
\hline ca-4CLL1 reverse & TAGCCGGAACTAGCAATCGT \\
\hline ca-DNAJ1 forward & ACGAGATGGTGCTGACGTAT \\
\hline ca-DNAJ1 reverse & AGTATTGTCCTGGCTGCACT \\
\hline caAAP4 forward & ATCTCTGCGGACTCATCCAG \\
\hline ca-AAP4 reverse & GGCCTTTCTCATGGAAGCAG \\
\hline ca-ABCG11 forward & CTACTGGCTAAGGCTGCTGA \\
\hline
\end{tabular}

Page 13/21 


\begin{tabular}{|ll|} 
ca-ABCG11 reverse & AGACGAATGAAGCACATGCC \\
\hline Actin forward & TAGGTGCCCAGAGGTTCTATT \\
\hline Actin reverse & ACCGCTAAGCACCACATTAC \\
\hline
\end{tabular}

Table 2. Primers designed to perform qPCR experiments with the shortlisted nine miRNAs

\begin{tabular}{|c|c|c|}
\hline miRNA & Stem loop primer & Forward primer \\
\hline $\begin{array}{l}\text { osa- } \\
\text { miR169 }\end{array}$ & GTTGGCTCTGGTGCAGGGTCCGAGGTATTCGCACCAGAGCCAAC GAATGG & GTGGGCATCATCCATCCTA \\
\hline $\begin{array}{l}\text { ppt- } \\
\text { miR1223 }\end{array}$ & GTTGGCTCTGGTGCAGGGTCCGAGGTATTCGCACCAGAGCCAAC TAGAGG & GGGGTTGTAGAGTCATGCA \\
\hline $\begin{array}{l}\text { aly- } \\
\text { miR398 }\end{array}$ & GTTGGCTCTGGTGCAGGGTCCGAGGTATTCGCACCAGAGCCAAC CATATG & GTTGGGGTCGACATGAGAA \\
\hline $\begin{array}{l}\text { gra- } \\
\text { miR482 }\end{array}$ & GTCGTATCCAGTGCAGGGTCCGAGGTATTCGCACTGGATACGACTTGGAA & AACACGCTTCCCAAAACCTC \\
\hline $\begin{array}{l}\text { gma- } \\
\text { miR4415 }\end{array}$ & GTTGGCTCTGGTGCAGGGTCCGAGGTATTCGCACCAGAGCCAAC CCATGT & GTTTGGGTTGATTCTCATCACA \\
\hline $\begin{array}{l}\text { mtr- } \\
\text { miR5261 }\end{array}$ & GTTGGCTCTGGTGCAGGGTCCGAGGTATTCGCACCAGAGCCAAC AGCCAA & GGGGTCATTGTAGATGGCT \\
\hline $\begin{array}{l}\text { ath- } \\
\text { miR167 }\end{array}$ & GTTGGCTCTGGTGCAGGGTCCGAGGTATTCGCACCAGAGCCAAC CCAGAT & GTTTGAAGCTGCCAGCATG \\
\hline $\begin{array}{l}\text { ath- } \\
\text { miR1886 }\end{array}$ & GTTGGCTCTGGTGCAGGGTCCGAGGTATTCGCACCAGAGCCAAC TTTTCT & GGGGGTGAGAAGAAGAAGA \\
\hline $\begin{array}{l}\text { mtr- } \\
\text { miR164 }\end{array}$ & GTTGGCTCTGGTGCAGGGTCCGAGGTATTCGCACCAGAGCCAAC TGCACG & GTTTTGGAGAAGCAGGGCA \\
\hline $\begin{array}{l}\text { Reverse } \\
\text { common }\end{array}$ & GTCGTATCCAGTGCAGGGT & \\
\hline \multirow[t]{2}{*}{ Actin } & Forward TAGGTGCCCAGAGGTTCTATT & \\
\hline & Reverse ACCGCTAAGCACCACATTAC & \\
\hline
\end{tabular}

Table 3. Assembly summary of contigs of mango ginger and ginger. 


\begin{tabular}{|lll|}
\hline & Mango ginger & Ginger \\
\hline Number of reads & 80496326 & 66561960 \\
\hline Average read length & 100 & 100 \\
\hline Average GC per reads & 44 & 48 \\
\hline Number of contigs & 307952 & 303878 \\
\hline Mean contig length & 845.32 & 692.32 \\
\hline Maximum & 15525 & 23113 \\
Contig length & & \\
\hline N50 & 1256 & 1005 \\
\hline N100 & 201 & 201 \\
\hline
\end{tabular}

Table 4. List of upregulated and downregulated genes

\begin{tabular}{|lll|}
\hline & Upregulated & downregulated \\
\hline Ginger leaves & 4CCL, ABCC5, PRT6, RSP2, FRS6, WRKY19, DNAJ1 & AAP4, ABCG11 \\
\hline Mango ginger leaves & 4CCL, ABCC5, PRT6, RSP2, AAP4, ABCG11 & FRS6, WRKY19, DNAJ1 \\
\hline Ginger rhizome & 4CCL, ABCC5, PRT6, RSP2, FRS6, WRKY19, DNAJ1, ABCG11 & AAP4 \\
\hline Mango ginger rhizome & $4 C C L$, ABCC5, PRT6, RSP2, DNAJ1, ABCG11, AAP4 & FRS6, WRKY19 \\
\hline
\end{tabular}

Table 5. Correlation analysis of miRNAs expression profiles and their target genes in response to $R$. solanaeserum

\begin{tabular}{|llllll|}
\hline \multicolumn{5}{|c|}{ Pearson correlation coefficient } \\
\hline Target genes & miRNA & Ginger leaves & Ginger rhizome & Mango ginger leaves & Mango ginger rhizome \\
\hline RPS2 & miR482 & -0.94 & -0.92 & -0.92 & -0.90 \\
\hline FRS6 & miR-1223 & -0.92 & -0.91 & 0.99 & -0.91 \\
\hline ABCC5 & miR-5261 & -0.94 & -0.91 & -0.97 & -0.95 \\
\hline ABCG11 & miR-169 & -0.95 & -0.98 & -0.95 & -0.98 \\
\hline AAP4 & miR-164 & -0.90 & -0.97 & -0.97 & -0.94 \\
\hline DNAJ1 & miR-167 & -0.93 & -0.90 & -0.97 & -0.93 \\
\hline WRKY19 & miR-398 & -0.912 & -0.94 & -0.95 & -0.97 \\
\hline 4CLL1 & miR-1886 & -0.96 & -0.98 & -0.97 & -0.90 \\
\hline
\end{tabular}


Figures

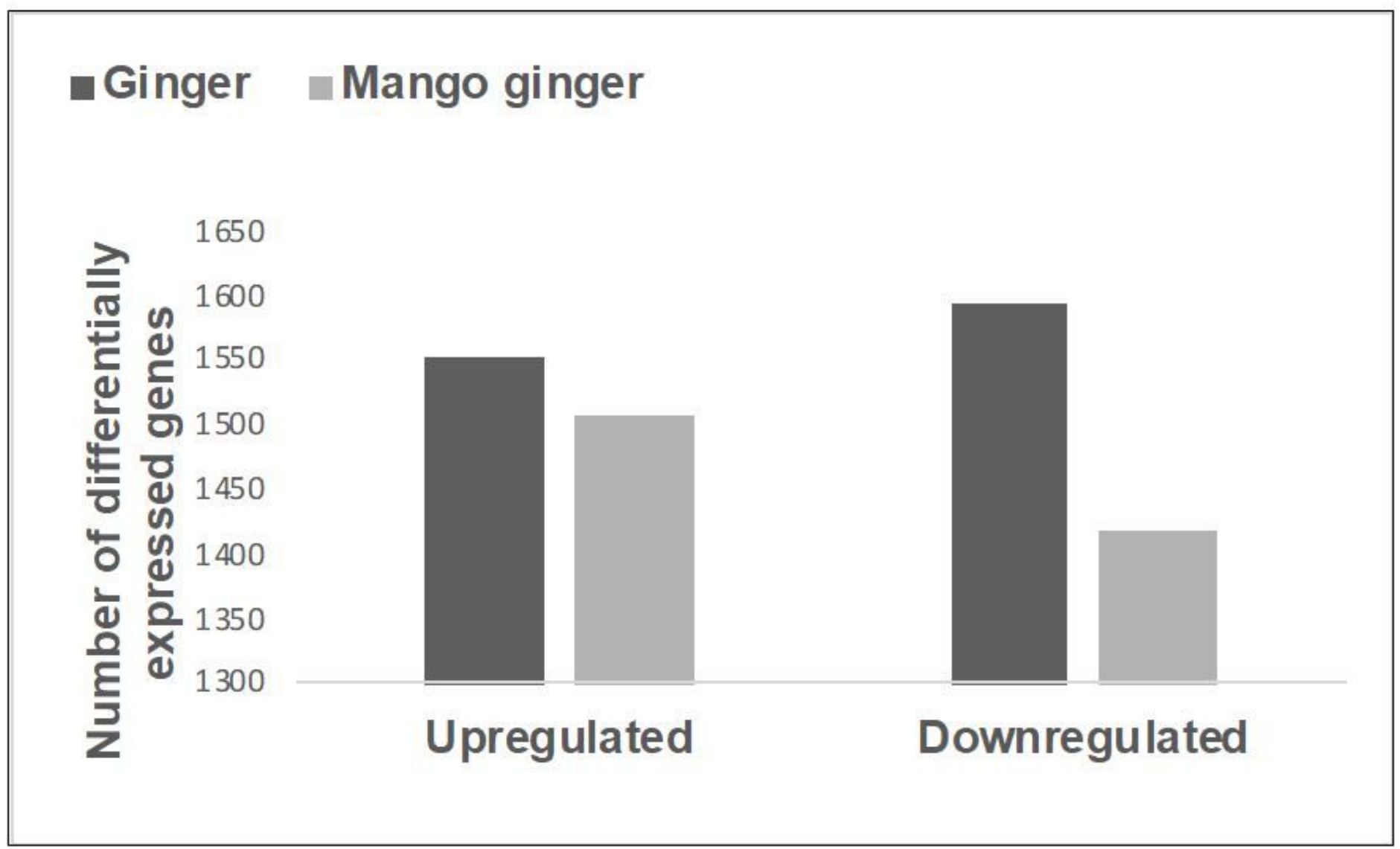

Figure 1

Numbers of differentially expressed known target genes in response to bacterial wilt 


\section{downregulated $\mathrm{Zn} \quad$ upregulated $\mathrm{Ca}$}

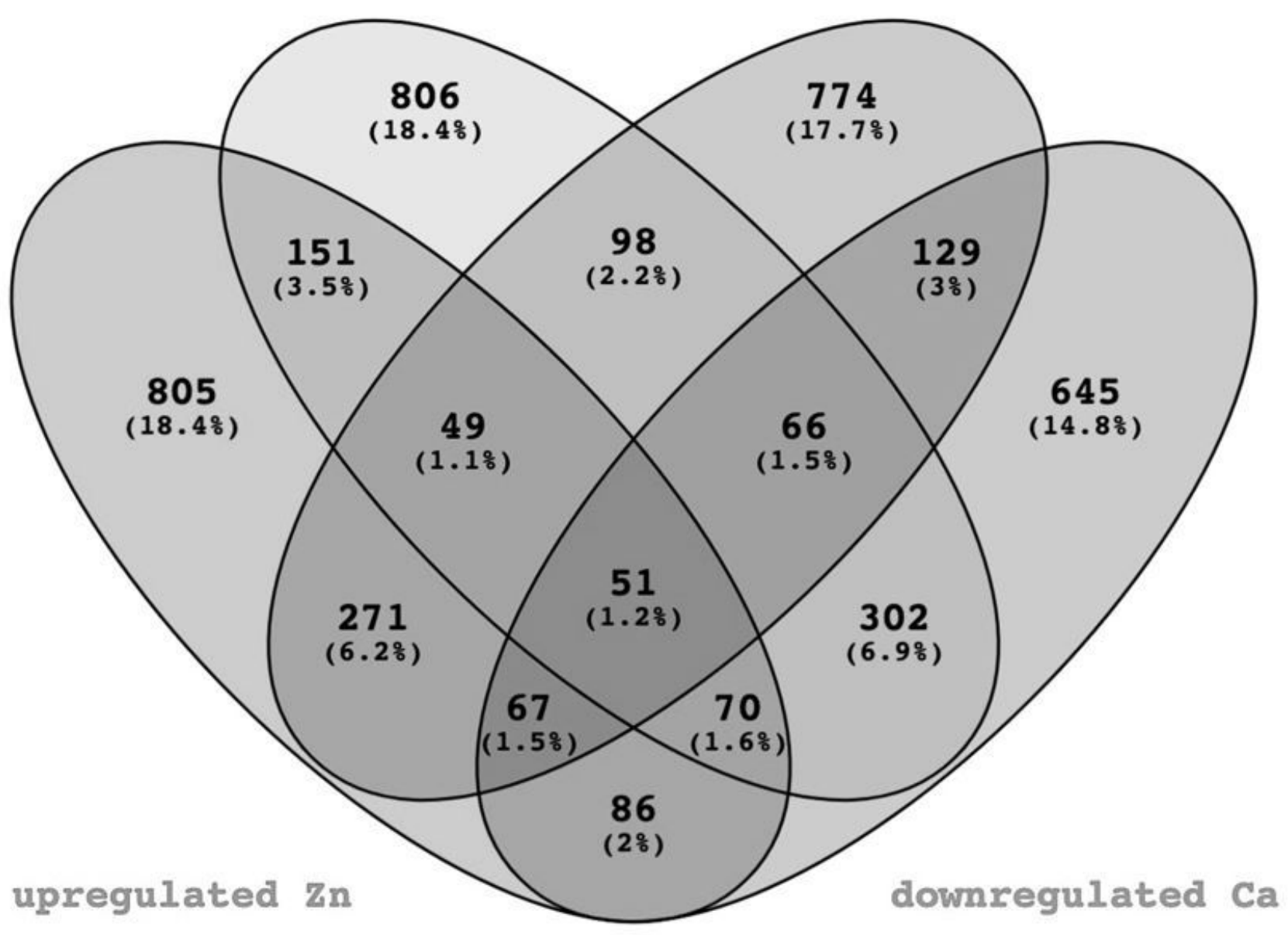

Figure 2

Venn diagram of differentially expressed target genes in response to bacterial wilt in two ginger species (ginger: $\mathrm{Zn}$ and mango ginger: $\mathrm{Ca}$ ) 


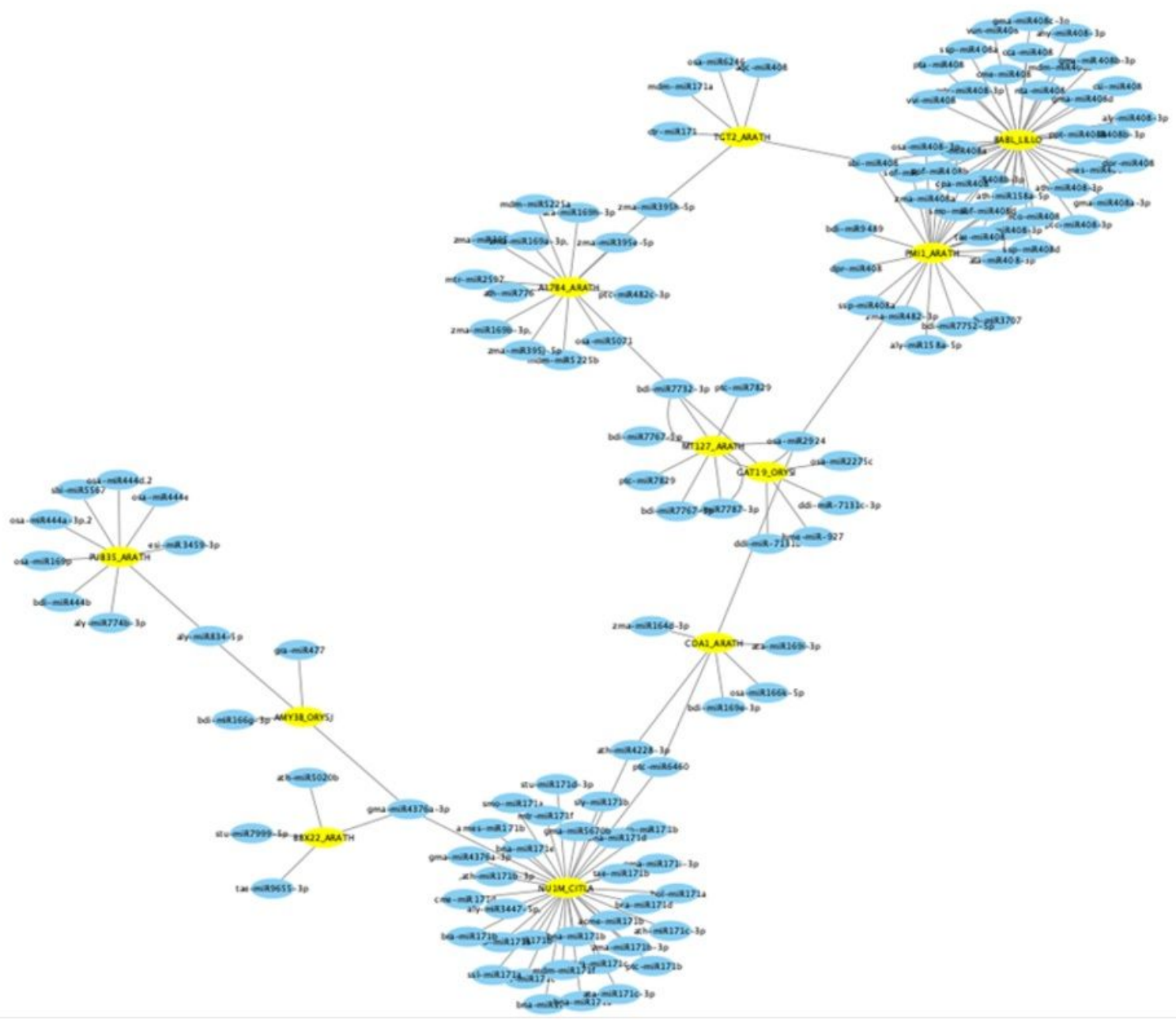

\section{Figure 3}

Regulation network constructed with targets and corresponding miRNAs. Few miRNAs targets and their corresponding miRNAs were chosen to explain complexity in network regulation. yellow indicates target genes and blue indicates corresponding miRNAs. 


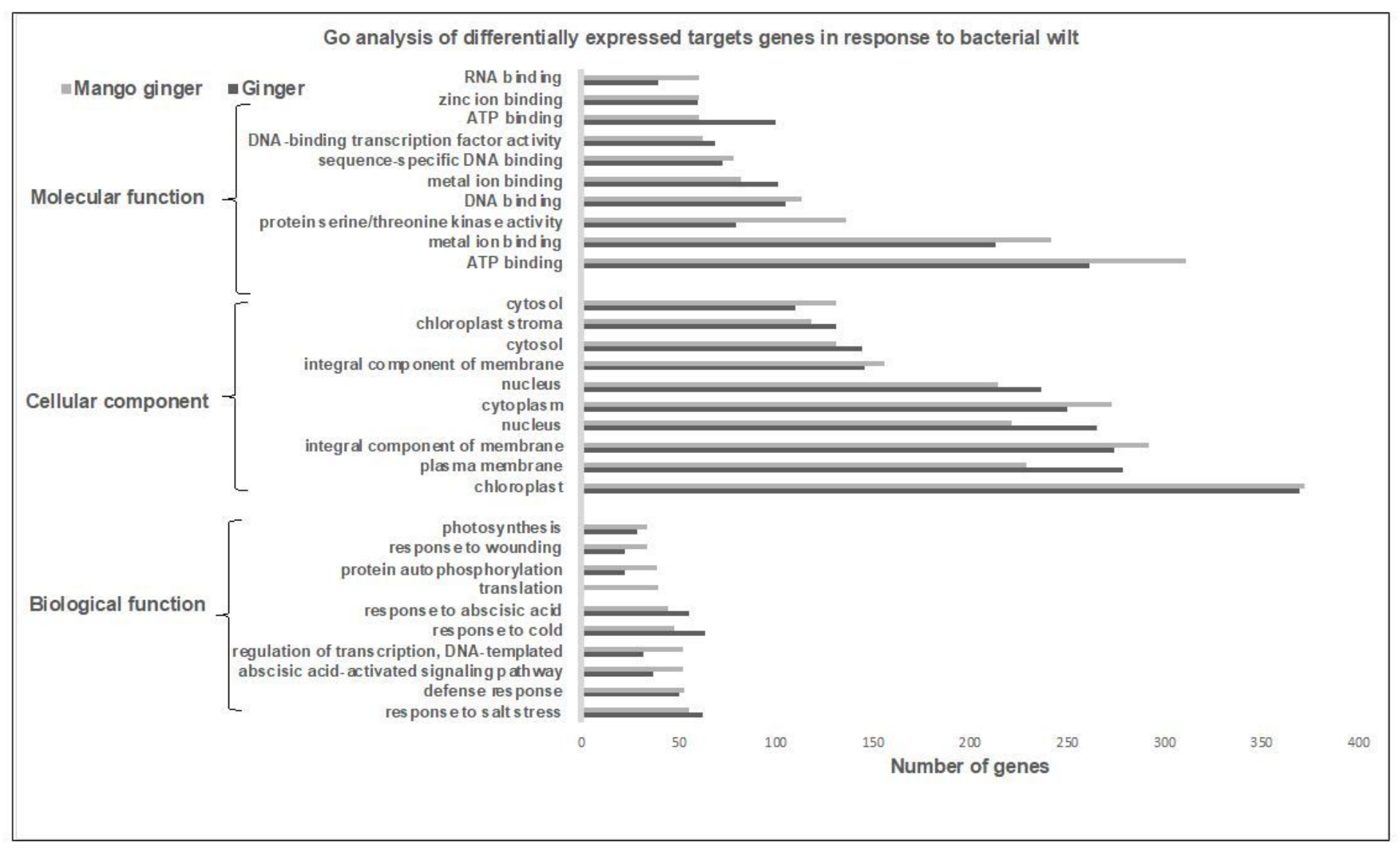

\section{Figure 4}

GO analysis of differentially expressed target genes in response to bacterial wilt. 


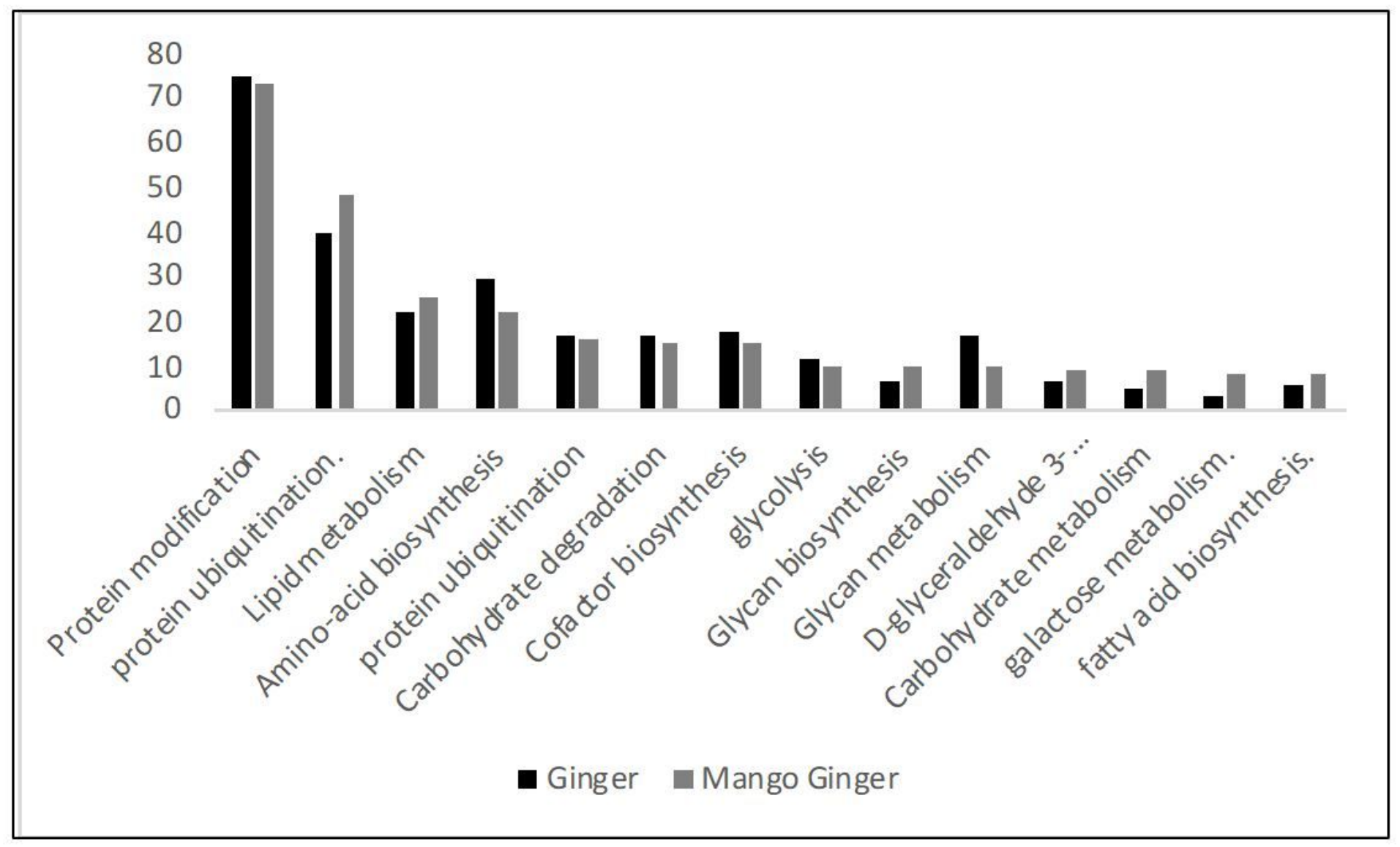

Figure 5

KEGG pathway analysis of differentially expressed target genes in response to bacterial wilt.
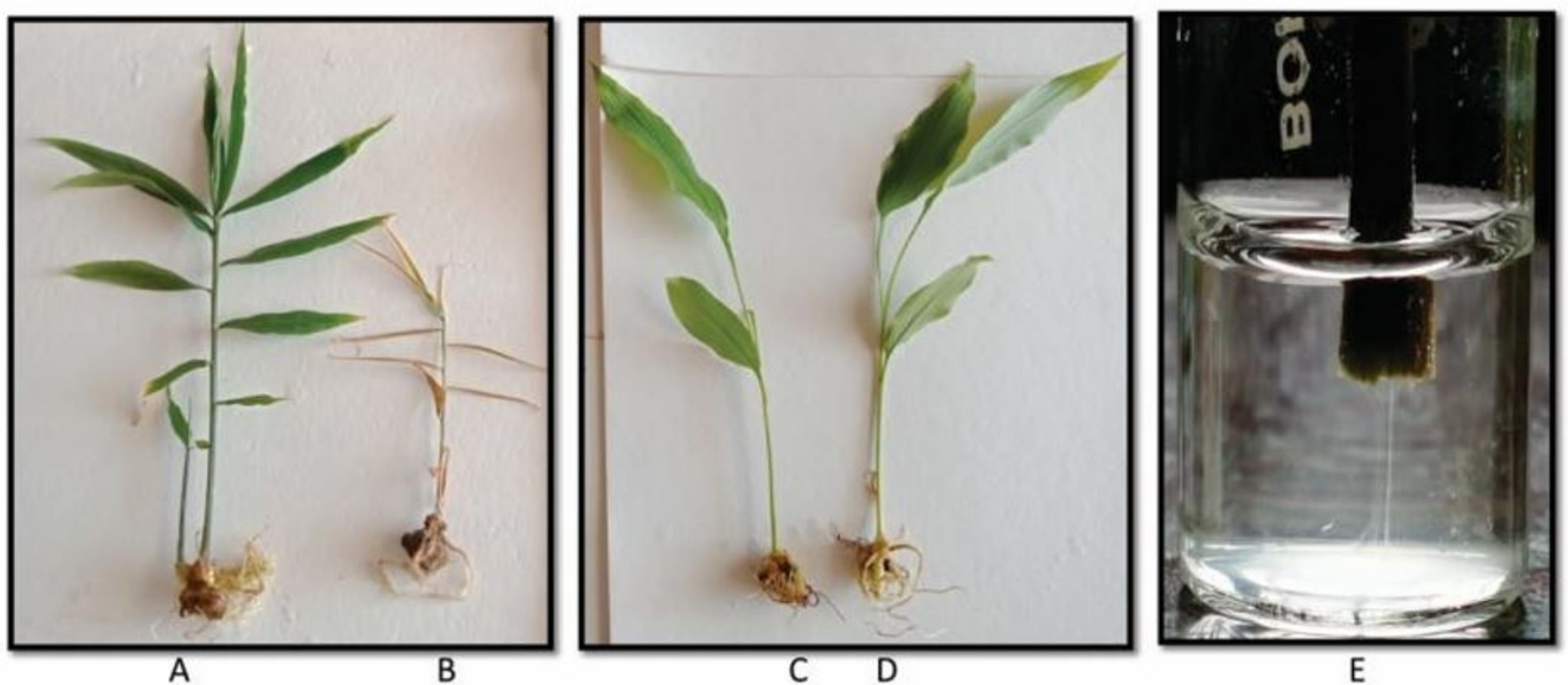

\section{Figure 6}

Figures showing the symptoms of control and inoculated plants of ginger and mango ginger at $5 \mathrm{dpi}$ (A) Control ginger (B) Inoculated ginger (C) Control mango ginger (D) Inoculated mango ginger (E) Milky white bacterial ooze from the infected 
pseudostem of ginger

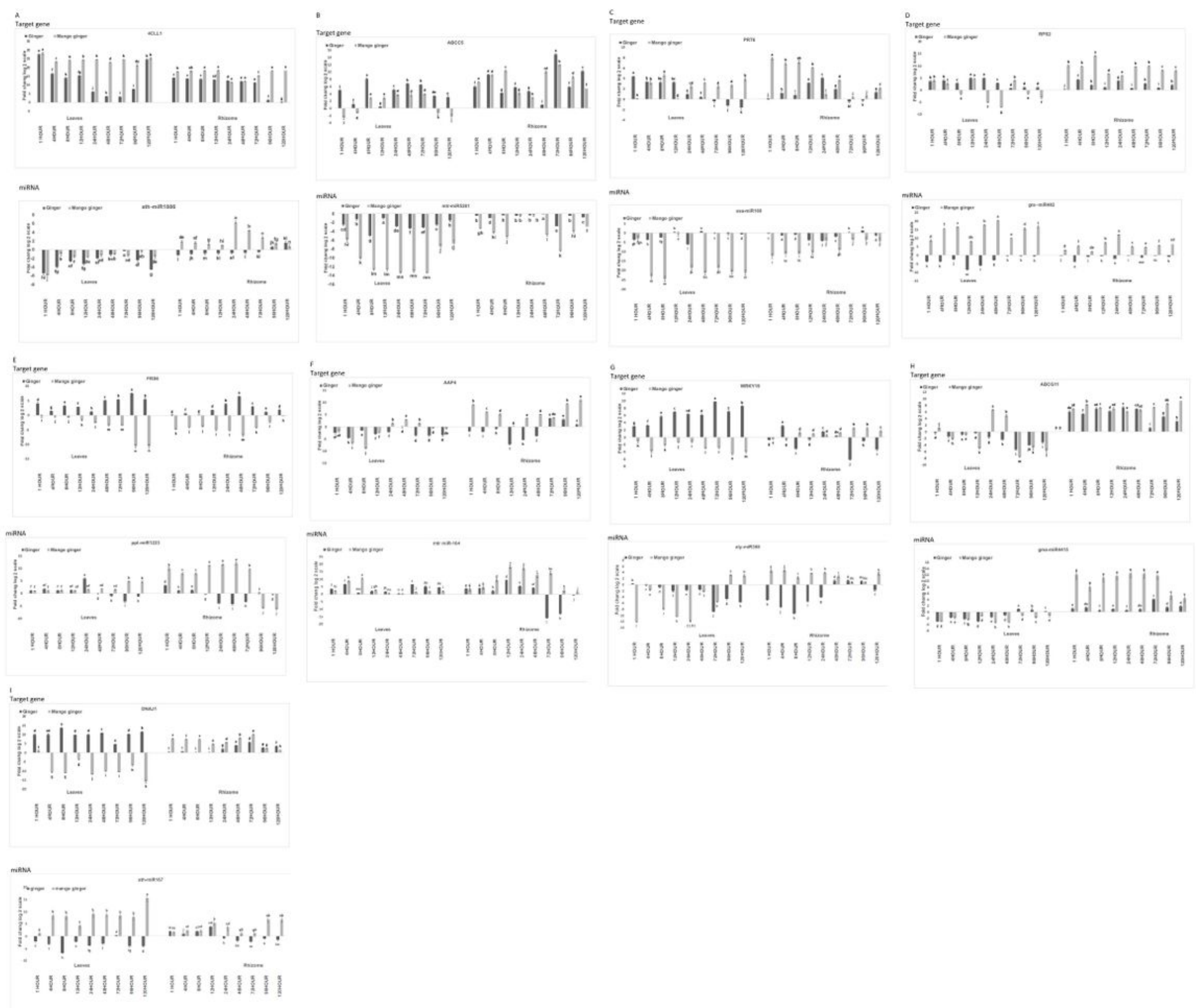

\section{Figure 7}

Normalized relative gene expression levels of nine miRNAs and targets in ginger and mango ginger leaf and rhizome tissues at different time intervals post inoculation with R. solanacearum. A. 4CLL1\& ath-miR1886, B. ABCC5\& mtr-miR5261, C. PRT6\& osa-miR169, D. RSP2\& gra-miR482, E. FRS6\& ppt-miR1223, F. AAP4 \& mtr-miR164, G. WRKY19 \& aly-miR398, H. ABCG11\& gmamiR4415 and I. DNAJ1\& ath-miR167

\section{Supplementary Files}

This is a list of supplementary files associated with this preprint. Click to download.

- Supplementaryfigures.docx

- Supplemntarydata.xlsx 